\title{
A Study on Growth and Performance of Dairy Sector in Nepal
}

\author{
Shuvam Shingh ${ }^{1 *}$, Chandan Sah Kalwar ${ }^{2}$, Sandesh Poudel ${ }^{2}$, Priya Tiwari ${ }^{2}$ \\ and Sitesh $\mathrm{Jha}^{3}$
}

\author{
${ }^{1}$ Warner College of Dairy Technology, SHUATS, Prayagraj, 211007, UP, India \\ ${ }^{2}$ Naini Agriculture Institute, SHUATS, Prayagraj, 211007, UP, India \\ ${ }^{3}$ Institute of Agricultural Sciences, BHU, Varanasi, 221005, UP, India \\ *Corresponding Author: shuvam.shingh079@gmail.com
}

\begin{abstract}
Dairy sector has been a vector in providing dairy products to the urban population and pull the urban capital into the rural areas. Dairy industries have been successful in creating a strong network between the dairy farmers and the consumers and have been established as a bridge between the urban and rural trade across the country. The entire dairy chain is dependent upon milk production. At present, Nepal contributes approximately $0.247 \%$ of the world's total milk production. Nepal's milk output is estimated to be 2.05 million metric tons. The per capita availability of milk in Nepal is around 158.9 grams per day, which is far below than the value recommended by World Health Organization (WHO). The current milk production growth rate should be raised to 4 percent per annum so as to meet the WHO recommended minimum value of $250 \mathrm{gm}$ per day per-capita milk consumption by the year 2025.The dairy sector in Nepal is the most important sub sector in Nepalese livestock production. Almost 28\% of the national GDP comes from the agriculture and livestock sector. However, the share of dairy sector in agricultural GDP of Nepal is $8 \%$ of the national GDP. Beside contributing to the GDP, the agriculture sector also provides employment to the two-thirds of the country's population. The cooperative sector in Nepal has been in the emerging state and is playing an important role in socioeconomic development of millions of rural families.
\end{abstract}

Keywords-Dairy; GDP; Per Capita availability; Milk production; Livestock; Sustainability.

\section{INTRODUCTION}

The organized dairy development activities in Nepal began only after 1952. The establishment of a Yak cheese factory in Langtang of Rasuwa district under the assistance of Food and Agriculture Organization (FAO) in 1953 is considered to be the pioneer activities in the dairy development of Nepal (FAO, 2010).

A large share in agricultural Gross Domestic Product comes from the Nepalese dairy sector. The co-operatives play an important role in agriculture and livestock sector, whose share in agricultural GDP of country has been 28 percent (NRB, 2018; Tiwari and Shingh, 2020). Dairy co-operatives help in establishing strong network and linkages in millions of rural households scattered across the country. Dairy co-operatives have helped immensely to establish a strong network and linkages among the rural population all over the country. The co-operative sector in Nepal has been in the emerging state and is playing an important role in socio-economic development of the country. At present the dairy sector of our country is contributing $0.247 \%$ percent of the world's total milk production. Nepal's milk output is estimated to be 2.05 million metric tons (FAOSTAT, 2019). The per capita availability of milk has also increased to a level of about 158.9 gram per day (RAN, 2015). This sector has its importance in reducing poverty through creating employment and income generating opportunities that is ensured through regular cash flow from urban to the rural areas (Neupane et al., 2018). The population growth rate of Nepal is found to be 1.35 percent per annum. Under this assumption, the current 
milk production should be raised by 4 percent so as to meet the WHO recommended minimum value of $250 \mathrm{gm}$ per day per-capita milk consumption by the year 2025. In contrast, current milk production growth stands only at 3.09 percent per annum (Upadhyay, 2017).

Present paper focuses on growth and performance of dairy sector in Nepal and provides recommendations to meet future challenges. A major fraction of milk is found to be handled by the unorganized sector in Nepal. Sweet shops, hotels, restaurants and tea shops which manufactures short to medium shelf-life milk products and are not recognized by Nepalese Dairy Act comes under the unorganized sector. There is no doubt regarding the dairy co-operatives playing a vital role in alleviating rural poverty. The formal sector or organized sector shares $20 \%$ of the total annual milk produced in the country (NEPC, 2017). The result of the study indicates that product development, milk quality, infrastructure support, and global competition could be the future challenges of Nepalese dairy sector.

\section{OBJECTIVES OF THE STUDY}

The objectives of this research are as followings:

1. To analyze the progress of dairy sector in Nepal.

2. To find out the limitations and opportunities of dairy sector in Nepal.

3. To examine the role of cooperatives in development of dairy sector and their challenges.

4. To propose the sustainable remedial measures for improving the overall performance of Nepalese dairy sector.

\section{MATERIAL AND METHOD}

The present research paper is descriptive and is based on secondary data. The secondary data has been obtained from various sources such as, Ministry of Agriculture and Livestock Development (MoALD, Nepal), Ministry of Finance (MoF, Nepal) and various reports of Dairy development Cooperation (DDC), Food and Agricultural Organization (FAO), National Agricultural Research council (NARC) and National Dairy Development Board (NDDB). The basic statistical tools such as percentage, growth rate, variation etc. is used for the economic analysis. The similar methodology was adopted by
(Deshmukh, 2014) for analyzing the growth and performance of dairy sector in India.

\section{RESULT \& DISCUSSION}

\subsection{Status of Dairy Sector in the World}

The dairy sector of Nepal is emerging, and its share to the global milk production is very low i.e 0.247 percent of the global milk share. India has been established as the largest milk producer in the world, producing 176.27 MT of milk per year sharing $21.32 \%$ of global milk production, followed by USA (97.76 MT/year, $11.82 \%$ of global milk production) and Pakistan (44.29 MT,5.35\% of global milk production). The annual milk production of Nepal as per the report published by FAOSTAT (2019) is 2.05 MT. Nepal's share in global milk production is $0.247 \%$ in the year 2017 .

From table 1 it is clear that the global milk production is rising tremendously to meet the requirements of the growing population. The world milk production in the year 1975 was only 424.73 MT, which is almost half of the present global milk production $(826.75 \mathrm{MT})$. Table 1 also reveals a slight drop in the annual milk production of several countries like China, New Zealand, UK and France. The top ten countries of the world are contributing around $62 \%$ of the world milk output till 2017.

The setup of modern dairy processing units with the application of scientifically advanced processing techniques and with several investments, innovations in all possible scale would make Nepal a major player in the world dairy market. 
International Journal of Environment, Agriculture and Biotechnology, 5(4)

Jul-Aug, 2020 / Available: https://ijeab.com/

Table 1: Largest Milk producing countries in the world (FAOSTAT, 2019)

\begin{tabular}{|c|c|c|c|c|c|c|c|c|c|c|c|}
\hline \multirow{2}{*}{\multicolumn{2}{|c|}{$\begin{array}{c}\text { Rank in } 2017 \\
\text { Country }\end{array}$}} & \multicolumn{5}{|c|}{ Production (Million tons) } & \multicolumn{5}{|c|}{ Share in percentage } \\
\hline & & 1985 & 1995 & 2005 & 2015 & 2017 & 1985 & 1995 & 2005 & 2015 & 2017 \\
\hline 1 & India & 44.02 & 65.37 & 95.62 & 155.69 & 176.27 & 8.58 & 12.10 & 14.75 & 19.43 & 21.32 \\
\hline 2 & USA & 64.93 & 70.44 & 80.25 & 94.634 & 97.76 & 12.65 & 13.04 & 12.38 & 11.81 & 11.82 \\
\hline 3 & Pakistan & 10.86 & 19.01 & 29.44 & 41.59 & 44.29 & 2.11 & 3.51 & 4.54 & 5.19 & 5.35 \\
\hline 4 & China & 4.76 & 9.46 & 32.02 & 36.28 & 34.87 & 0.92 & 1.75 & 4.94 & 4.52 & 4.21 \\
\hline 5 & Brazil & 12.57 & 17.13 & 25.53 & 34.86 & 33.74 & 2.45 & 3.17 & 3.94 & 4.35 & 4.08 \\
\hline 6 & Germany & 33.63 & 28.63 & 28.48 & 32.71 & 32.69 & 6.55 & 5.30 & 4.39 & 4.08 & 3.95 \\
\hline 7 & $\begin{array}{l}\text { Russian } \\
\text { Federation }\end{array}$ & 0.00 & 39.31 & 31.15 & 30.79 & 31.18 & - & 7.27 & 4.80 & 3.84 & 3.77 \\
\hline 8 & France & 28.40 & 26.069 & 25.71 & 25.93 & 25.26 & 5.53 & 4.82 & 3.96 & 3.23 & 3.05 \\
\hline 9 & $\begin{array}{c}\text { New } \\
\text { Zealand }\end{array}$ & 7.88 & 9.29 & 14.64 & 21.94 & 21.37 & 1.53 & 1.72 & 2.25 & 2.73 & 2.58 \\
\hline 10 & UK & 16.02 & 14.84 & 14.47 & 15.32 & 15.26 & 3.12 & 2.74 & 2.23 & 1.91 & 1.84 \\
\hline \multicolumn{12}{|c|}{ Nepal's share to global milk production } \\
\hline & Nepal & 0.81 & 1.01 & 1.35 & 1.86 & 2.05 & 0.15 & 0.18 & 0.20 & 0.23 & 0.24 \\
\hline & World & 512.98 & 540.07 & 648.22 & 801.13 & 826.75 & 100 & 100 & 100 & 100 & 100 \\
\hline
\end{tabular}

\subsection{Dairy Sector Scenario in Nepal}

As the dairying sector in Nepal is in the developing stage, its position in terms of per capita availability is one of the lowest. The per capita availability of milk was about $132.88 \mathrm{gm}$ per day in 1985 which has declined to 129.30 gm per day in 1995. However, the present level of per capita availability is $158.9 \mathrm{gm}$ which is much lower than the recommended value of WHO (250gms) and even less than $220 \mathrm{gm}$ recommended by the Nutritional Advisory Committee of the Indian Council of Medical Research (ICMR). The current milk production of Nepal as per the report of Food and Agricultural Organization in the year 2017 is 2.05 MT.

As per the statistical information collected from Nepalese Agriculture- 2014/15, MoAD, total milk production in Nepal was 1724823 MT out of which 1153838 MT is from buffalo and 468913 MT from cow. The total buffalo population was estimated to be 5133139 and that of cattle population was 557669. Likewise, the total milking cattle were 1025947 and milking buffaloes were 135164 and they produced 1167154 milk. Out of the total livestock population, only $13 \%$ of the cattle and $26 \%$ of the buffaloes are of improved breeds (NARC, 2016). Jersey, Holstein, Brown-Swiss, Ayrshire and Sahiwal and their cross-bred cows were the breeds of cows, whereas the buffaloes included local, improved such as Murrah and their crosses. Buffalo milk shares about $65 \%$ of the total milk production in Nepal (MoAD, 2016).

The decentralized system of governance in Nepal shifted from the development region to the province system in the year 2015.The data tabulated below in the table shows various milch animal population in different provinces of Nepal. Province no.1 holds the maximum cattle population whereas the maximum buffalo population is found in province no.5. Province no. 2 doesn't hold any yak whereas the maximum yak and sheep population is hold by province no.6. Likewise, province no.1 holds the first position on the goat and pig population. The total cattle population as per the report of livestock statistics of Nepal,2017 is 6430397. 
International Journal of Environment, Agriculture and Biotechnology, 5(4)

Jul-Aug, 2020 / Available: https://ijeab.com/

Table 2: Population of animals in various provinces of Nepal (Livestock statistics ofNepal,2017)

\begin{tabular}{|c|c|c|c|c|c|c|}
\hline Province & Cattle & Buffalo & Yak/Chauri & Sheep & Goat & Pig \\
\hline Province 1 & 1601707 & 455638 & 13007 & 48365 & 2277659 & 458723 \\
\hline Province 2 & 697881 & 424711 & - & 12118 & 1306800 & 27839 \\
\hline Province 3 & 832320 & 588984 & 11354 & 39836 & 2484855 & 84763 \\
\hline Province 4 & 476367 & 526689 & 10664 & 67954 & 1283467 & 81939 \\
\hline Province 5 & 1040251 & 675601 & 11 & 134320 & 1835436 & 134424 \\
\hline Province 6 & 717636 & 170314 & 13083 & 223272 & 994927 & 27471 \\
\hline Province 7 & 1064235 & 332452 & 746 & 87019 & 1041986 & 55038 \\
\hline Total & 6430397 & 3174389 & 48865 & 612884 & 11225130 & 870197 \\
\hline
\end{tabular}

Table 3: Animal Population Trend over different years in Nepal

(Livestock Statistics of Nepal, 2016)

\begin{tabular}{|c|c|c|c|}
\hline Year & Total Animal & Total Milking Animal & \% of Milking Animal \\
\hline $2005 / 06$ & 11207802 & 1988140 & 17.74 \\
\hline $2006 / 07$ & 11411092 & 2033166 & 17.82 \\
\hline $2007 / 08$ & 11587221 & 2073711 & 17.90 \\
\hline $2008 / 09$ & 11855684 & 2144371 & 18.09 \\
\hline $2009 / 10$ & 12036244 & 2207450 & 18.54 \\
\hline $2010 / 11$ & 12219700 & 2265766 & 18.82 \\
\hline $2011 / 12$ & 12378083 & 2330000 & 19.14 \\
\hline $2012 / 13$ & 11515895 & 2395387 & 19.08 \\
\hline $2013 / 14$ & 12422528 & 2370350 & 19.11 \\
\hline $2014 / 15$ & 12409480 & 2371111 & 19.10 \\
\hline $2015 / 16$ & 12471617 & 2381519 & 20.27 \\
\hline $2016 / 17$ & 12525485 & 2539041 & \\
\hline
\end{tabular}

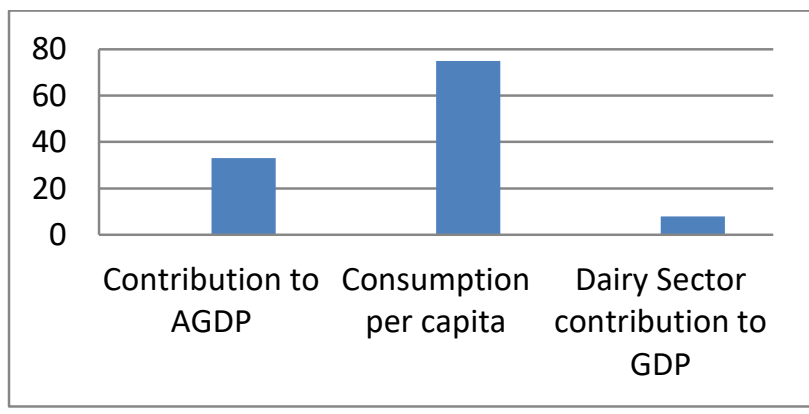

Fig 1: Nepal Dairy sector at a glance.

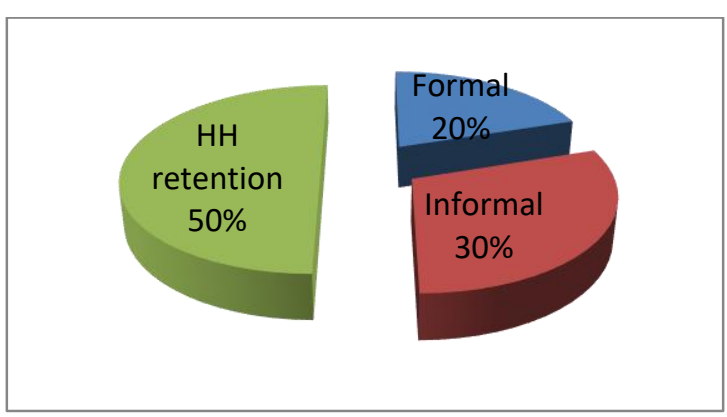

HH Retention: Household Retention

Fig 2: Distribution of Milk (COMP-NDDB,2017) 
From the bar graph mentioned above it is clear that, Nepal is an importer of milk and milk products to fulfill the present needs of its population. Milk, cream powder, butter, butteroil, cream liquid and cheese are the major products that are imported to Nepal. Dairy sector contributed nearly 33 percent of the AGDP (Agricultural Gross Domestic Product) and 8 percent of total GDP. The buffalo population in Nepal bears a considerably shorter lactation period of 242days, whereas the cows of Nepal has an average lactation period of 286 days which is sound.

\subsection{Ration and its effect on milk production in Nepal}

Balanced Ration is the quantity of feed that provides the necessary nutrients required for proper growth, development, gestation and lactation of animals. In
Nepal, crop residues, straw of wheat and rice, stovers of maize, leaves of trees and other green fodders cultivated by farmers are the prime sources of feed for animals. Beside these, maize is used as concentrate followed by brans of rice and wheat, oilseed cakes of soybean, mustard, sunflower and other byproducts of legumes. These concentrates used are not sufficiently produced in Nepal. Thus, they are imported from India and other countries. Grains of legumes are substantial source of protein. Osti et. al, (2013) found that milk production was less $(8 \mathrm{~kg} / \mathrm{d} / \mathrm{head})$ prior to bypass protein $(\mathrm{BP})$ feeding, while higher during BP feeding (10.0 $\mathrm{kg}$ /animal/day) was provided. The feed supply of Nepal is not sufficient to meet the demand of dairy animals. There is shortfall of $38 \%$ in crude protein, $42 \%$ in metabolizable energy and $33 \%$ in dry matter (Osti,2020).

Table 4: Crop residues and by-products available (\%) in Nepal (MoAD,2013)

\begin{tabular}{|c|c|c|c|c|c|}
\hline Crops & Main Product & Residues & Oil Meals & Oil Cakes & Bran/Husk \\
\hline Rice & 14.99 & 9.27 & - & - & - \\
\hline Maize & 66.56 & 82.30 & - & 97.71 & 76.28 \\
\hline Millet & 1.018 & 1.68 & - & - & - \\
\hline Wheat & 5.75 & 3.55 & - & - & 6.57 \\
\hline Barley & 0.113 & 0.07 & - & - & 17.15 \\
\hline Buckwheat & 0.033 & 0.021 & - & - & - \\
\hline Oilseeds & 0.596 & 0.143 & 99.95 & 0.76 & - \\
\hline Sugarcane & 9.75 & 1.01 & - & - & - \\
\hline Cotton & 0.005 & 0.000069 & 0.05 & 0.000732 & - \\
\hline Pulses & 1.19 & 1.96 & - & 1.53 & - \\
\hline Total & 100 & 100 & 100 & 100 & 100 \\
\hline
\end{tabular}

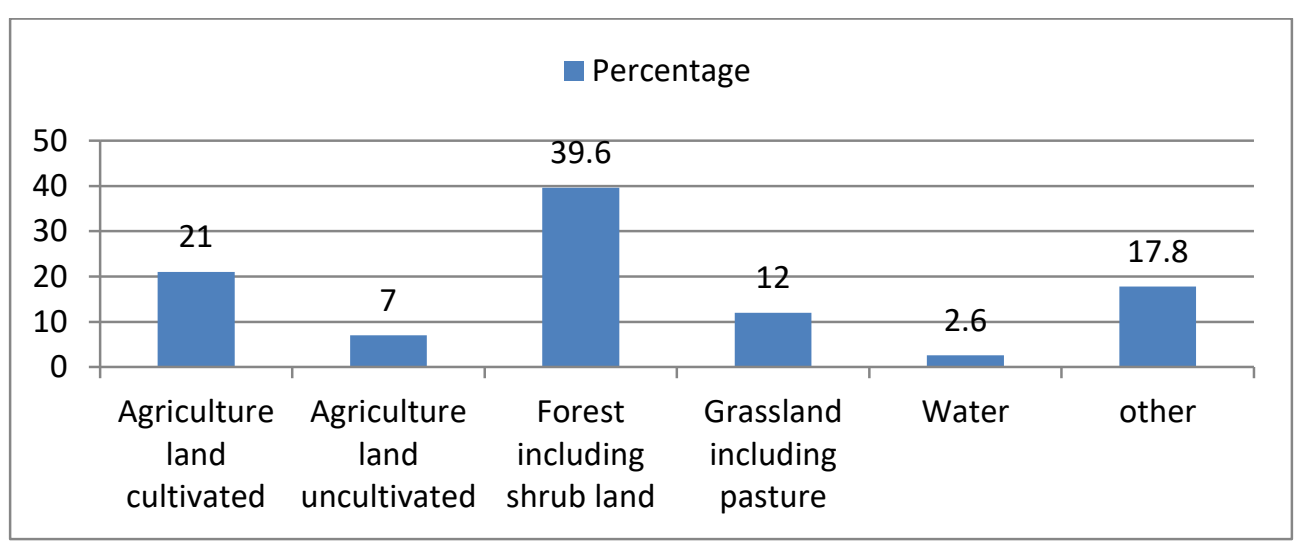


Fig 3: Land Use Statistics in Nepal

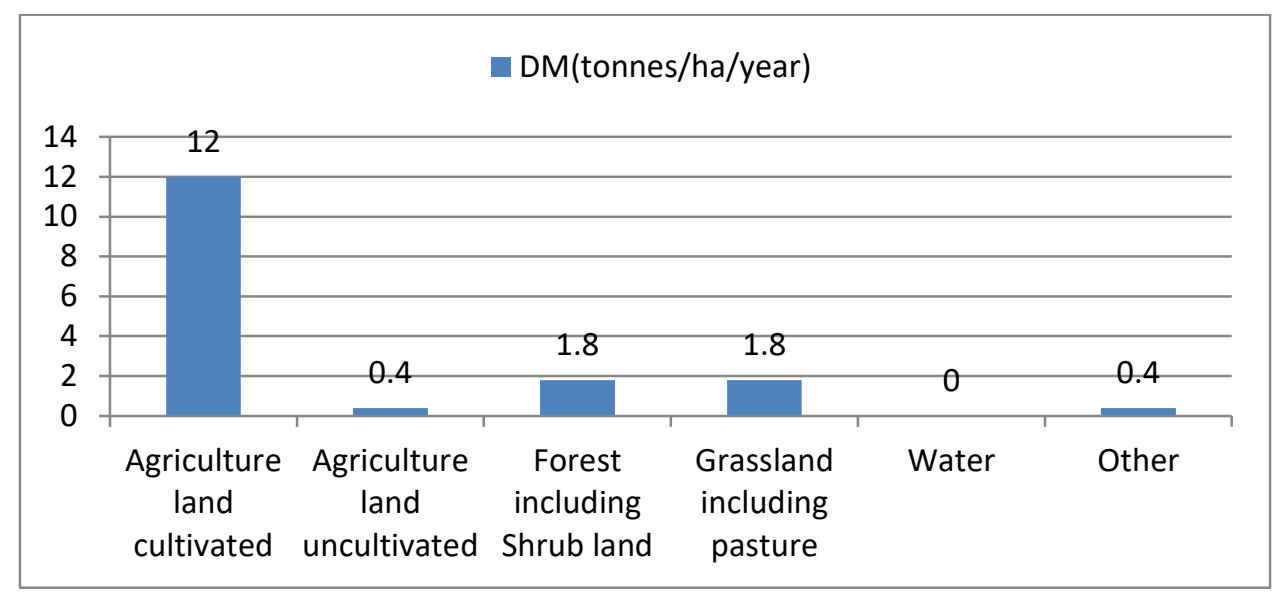

Fig.4: DM (Dry Matter) in tonnes/ha/year in different land use pattern

When we see prior to 100years then it is found that people used to feed only roughages to their animals and later use of concentrates increased the yield of milk and then the concept of total mixed ration (TMR) was popular and it is found that animals supplemented with TMR were found to be free from nutritionally related off feed, milk fat depression and indigestion problems (Schingoethe, 2017) .Total mixed rations are commonly being fed to dairy animals in other countries but still people in Nepal are compelled to feed roughages to their animals due to poor quality, lesser availability and higher prices of the concentrates (De Vries and Kaylegian, 2018).

\subsection{Pattern of Flow of Raw milk}

The latest milk production of Nepal as per the data obtained in the year 2017 was 2.05 MMT (FAOSTAT, 2019). Out of the total milk production, only $20 \%$ of the total milk was utilized by the formal sector (NEPC, 2017).

The milk is produced by the dairy farmers and the surplus milk is distributed either via formal and informal trading methods. The formal sector in Nepal comprises of the MPCS (Milk Producers Cooperative Society), MCC (Milk Chilling Centers), Milk processing plants and dairy cooperatives. The flow of milk in the formal sector passes from the MPCS to the MCC and finally to the milk processing plants. The milk producer's cooperative society is the organization comprising of the dairy farmers and functions to collect the raw milk at village and grassroot level. The milk collected from the MPCS is transported to the milk chilling centers where they are chilled and temporarily stored. From the MCC the milk is then transferred to the milk processing plants in the large tankers which are facilitated with adequate refrigeration requirements. Similarly, a small volume of milk directly passes from MPCs to Cow milk cheese factories and from farmers to the Yak cheese factories (FAO, 2010).

Tracking the milk passing through various channels either formal or informal is not an easy task in Nepal due to the lack of advances in the traceability system. The milk in Nepal is mainly supplied to the informal sectors which accounts for approximately $80 \%$ of the total annual milk production. In the informal sector, the milk is mostly handled by the individual households, tea shops and the sweet meat shops. The vector for the informal milk trading in Nepal is mostly individual farmers and the milk contractors. This pattern of flow of raw milk in Nepal can be illustrated via a chart shown below. 


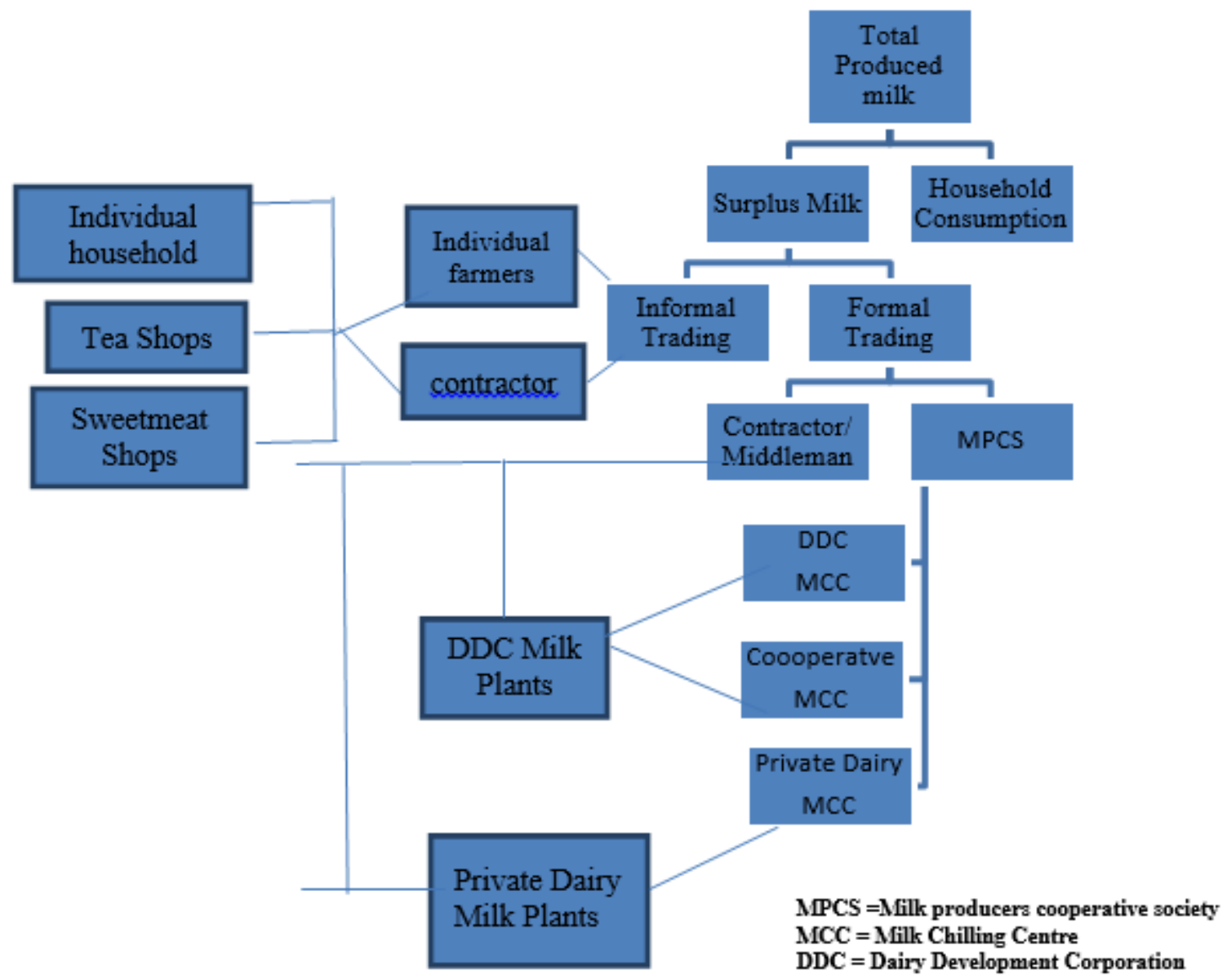

Fig 5: Flow patterns of milk in Nepal

(FAO,2010)

\subsection{Milk Production and Per Capita Availability Projection}

According to the data taken from FAOSTAT, (2019) and (Nepal Population, 2020), the annual milk production and the human population in the year 2017 were 2.05 MMT and 27632681 respectively. The per capita availability was calculated by dividing the total milk production with the human population and was expressed in grams per day. The per capita availability was found to be 203.49 gm per day in the year 2017 which was far less than the recommended value of WHO $(250 \mathrm{gm})$. It has been estimated that the annual milk production growth rate of Nepal is $3.09 \%$ (Upadhyay, 2017) and the population growth rate is $1.35 \%$ per annum (Nepal Population, 2020). 


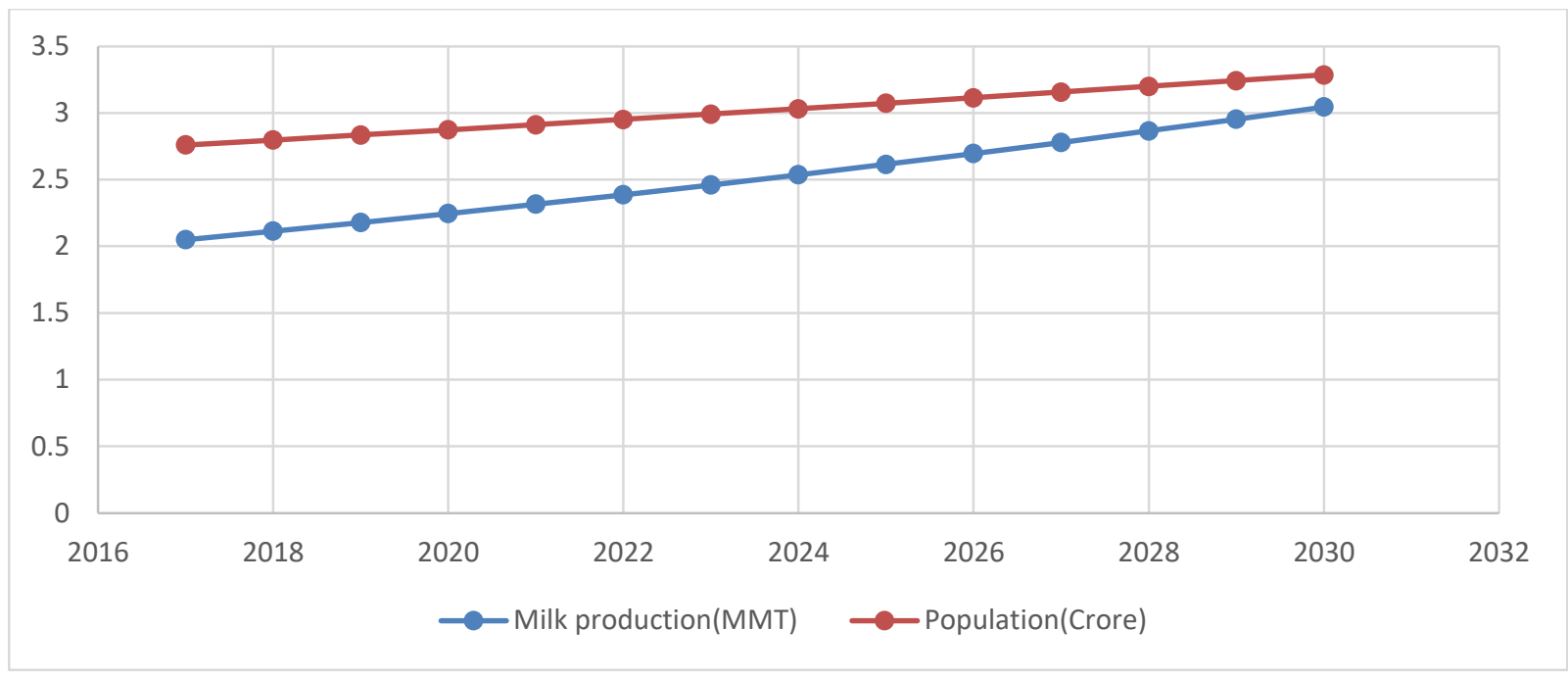

Fig 6: Projection on Annual Growth Rate Required to meet Milk Consumption Recommended By FAO/WHO By 2030.

The projected value of milk production was calculated by considering $3.09 \%$ annual growth rate i.e. current rate and the total milk production for the year 2017-2030 were extrapolated. Likewise, the human population for the various years were estimated by considering $1.35 \%$ annual growth rate and the population for the year 20172030 were extrapolated. The population and the milk production for the year 2030 was estimated to be 3.28 crores and 3.044 MMT respectively. The value of the per capita availability determined on the year 2030 is 253.89 gm per person per day which is just above the recommended value provided by WHO (250gms). Thus, with the same growth rate in milk production $(3.09 \%$ per annum) and population ( $1.35 \%$ per annum), the recommended value of milk availability would be achieved by 2030 .

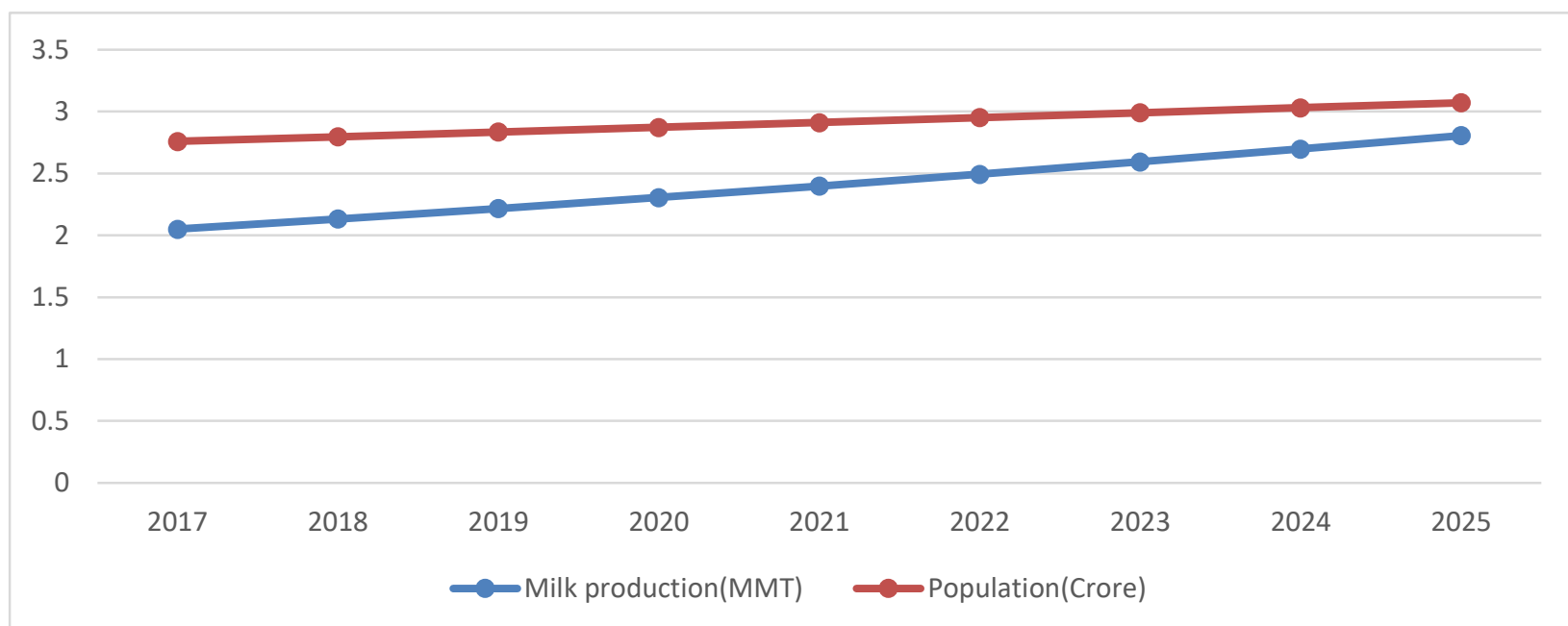

Fig.7: Projection on Annual Growth Rate Required to meet Milk Consumption Recommended By FAO/WHO By 2025

Figure 7 represents the projection on annual growth rate required to meet the milk consumption recommended by FAO/WHO by 2025 . In order to attain the recommended value of per capita availability by 2025 , the current milk production growth rate has to be increased to $4 \%$ per annum assuming the static population growth rate i.e.
$1.35 \%$ per annum. The total milk production in the year 2025 at $4 \%$ annual growth rate would be 2.80 MMT while the population at that period of time would be 3.07 crores.

Hence, the value of per capita availability estimated by 
dividing the total milk production by total population is 250.16 gm per person per day which is just above the recommended value of WHO (250gms).

\subsection{Limitation and Opportunities of Dairy sector in Nepal}

According to the World Bank collection of development indicators, the rural to urban population ratio of Nepal is approximately 8:2 i.e approximately $80 \%$ of the Nepalese reside in the rural sector. A major fraction of rural population of Nepal seem to be engaged in agriculture and livestock rearing which makes the rural sector a major milk producer in the nation. But because of the lesser availability of the assured market, the producers do not have an incentive to invest in good breeding stock, feeds, or veterinary medicine and services. Lack of these inputs affect the productivity which eventually reduces profit (Sharma and Banskota, 2002). Moreover, the dense population, lower milk production and availability causes the demand escalation of milk and milk products in the urban region. Similarly, because of the low purchasing power of the consumers, the effective demand for milk at local levels is also low. Hence, it is necessary to transport milk to major urban areas for marketing. At the same time the price the cooperatives pay to farmers does not match growing feed prices (Shrestha, 2000). Nepal has tremendous potential for increasing dairy livestock production and productivity. Buffalos in Nepal are also slaughtered for the production of meat and meat-based food products. Buffalo meat accounts for $54 \%$ of the total meat produced in the country (MoAD, 2016). Milk market in formal sector or organised sector contributes about $20 \%$ of the total annual milk produced in the country (NEPC,2017). The bovine population of 9604786 produces 2.05 million tonnes of milk annually (per capita availability of milk is 158.9 gms per day), whose contribution is yet below the recommended value of WHO (i.e. $250 \mathrm{gms}$ per day). The production and productivity of cattle in Nepal is very low with 519.56 litre per lactation as compared to world average $2038 \mathrm{~kg}$ per lactation, which requires a lot of improvement (Thompkinson and Sabikhi, 2012).

Hence, there is need of great improvement in the dairying and animal husbandry systems in Nepal. There is huge variation in productive and reproductive performance of cattle in Nepal. To make dairy sectors more commercial there is need and opportunities to increase productive and reproductive performance of cattle which can be achieved by cross breeding and hybridization (Paneru et al., 2015).

All over the country, the cattle and buffalo population are evenly distributed. It creates opportunity for the farmers to generate benefits from longer duration of lactation in cattle and high fat content of buffalo milk, both the factors leading to sound income. Huge population density in urban areas has created a significant demand for milk and dairy products which is impacting the milk market to grow and flourish (FAO, 2010). The increasing number of dairy plant schemes under DDC and strong channel of dairy cooperatives from the grassroot level to the central level has strengthened the dairy industry and provided a supportive environment to the dairy farmers. The influencing activities of NGOs like providing technical support, veterinary care service and involvement of private dairy sector has become sensational support and hope to the small-scale milk producer (Sharma and Banskota, 2002).

Despite the opportunities mentioned above, there are several other constraints relating to dairy sector development in Nepal. The depletion of animal feeding base resulted due to the deterioration of the forest areas for the various purposes like timber and fuel wood has affected the dairy sector adversely (Pande,1997). The unavailability of green fodder and quality feed adversely affects animal productivity. Moreover, poverty and illiteracy among the livestock raisers severely hits their ability to respond to the new opportunities and cope with the dynamic situation. Illiteracy complicates the extension learning process as they require more face to face communication. Above all, the uncommonness of the heifer rearing practice and lack of cost-effective heifer rearing technology has resulted in the critical shortage of the productive dairy animals (Sharma and Banskota, 2002). Upadhyaya et.al, (2000) studied the scenario of the dairy cooperatives in Nepal and concluded that the dairy cooperatives do not buy milk from their regular suppliers during the flush seasons. Those days of the week, when the private and public dairies do not buy milk from the dairy farmers are termed as "milk holidays." The main reason behind the milk holidays could be the lesser demand of milk and milk products among the consumers and lack of milk storages capacities in the processing plants. With an aim to compensate a possible milk holiday, Nepal is going to export 30000 litres of milk to India. Due to low domestic demand during the flush period exporting milk is an effective measure to avoid the problem. Production cost 
of milk in Nepal in comparison to India is naturally higher as Nepal is dominated by non-commercial farmers. Milk production drops by almost 30\% during lean season (April-August) which becomes insufficient to fulfill the market demand as milk consumption is going high. The deficit in milk production can be well combated by promoting powder milk as an alternative source of milk production as well as good support from government in building farmers capacity and introducing better dairying technologies. Also, low milk price is one of the major limitations in Nepal followed by lack of proper government milk policy and inadequate milk processing industries (Timsina and Regmi, 2009).

\subsection{Dairy Co-operatives and their challenges}

The establishment of dairy cooperatives in Nepal was the result of the implementation of the first five-year plan in the year 1956-61. The first dairy cooperative was formed at Tusal village of Kavre district. Though the dairy cooperative activities got initiated in the early 60s' their effective activities were observed only after December 1981, when DDC initiated the milk producers-oriented program by participating the farmers to form their own Milk Producer Association (MPAs). The MPAs thus formed were not provided with the legal status and they functioned for milk trade and support to milk production. Later on, MPAs were transformed into Milk Producers cooperative society (MCPS) in February 1989 to make them function autonomously. The MPCS are governed by cooperative Act 1992. The functions of these MPCSs is to gather milk from the dairy farmers, test its quality, transport it for selling to the nearest milk processing plants, receive payment for the milk and distribute the payment to the individual milk supplier farmer. The dairy cooperatives in Nepal functions in 3-tier system (FAO,2010).
The first tier is MPCSs primary level cooperatives, second level is District Milk Producers Cooperative Unions (DMPCUs) of different MPCSs as District bodies. Their main theme is to deliver programs designed to support the increased production and processing of milk and milk products and also to contribute to the financial and social upliftment of the rural milk producers. The third tier is Central Dairy Cooperative Association Limited Nepal (CDCAN). CDCAN is registered as their central-level cooperative organization established in 1993, mainly focuses on increasing economic benefits to the milk producers and making the country self-reliant in clean and high-quality milk and milk related products. Moreover, it also implements policy advocacy activities at the central level to represent the interest of member organizations (Upadhyay et.al., 2001).

The milk processing plants functions for the processing of raw milk and manufacturing the value-added products from the milk. They are the key elements of the formal sector of milk distribution. They help in maintaining a regular standard and balance of milk distribution throughout the region. They are the bridge via which the rural milk and resources and urban capital can be interlinked. The dairy sector in Nepal is characterized by scattered, small scale, unorganized milk animal holders; inadequate and inappropriate animal feeding and health care; low productivity; an inadequate basic infrastructure for provision of production in puts and services. Moreover, lack of an assured year-round remunerative producer price for milk, inadequate basic infrastructure for collection, transportation, processing and marketing of milk is another aspect of the Nepalese dairy sector. Low productivity of the milch animals is a serious constraint to the dairy development in Nepal (GOEC Nepal, 2012). 


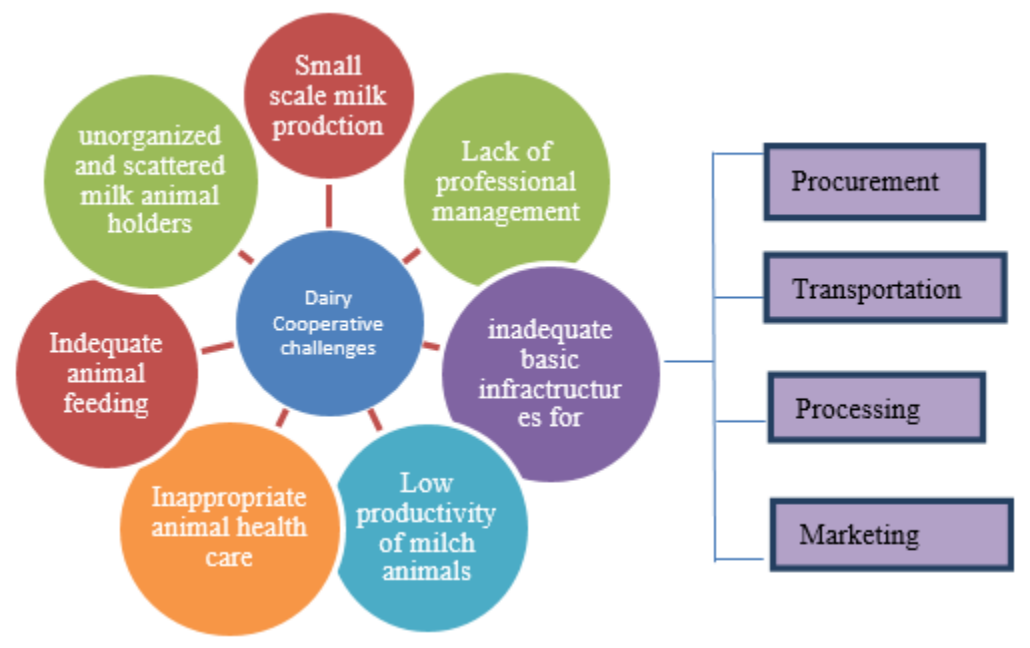

Fig. 8: Challenges faced by the Dairy Co-operatives

\subsection{Sustainable remedial measures and suggestions}

To overcome the challenges faced by dairy cooperatives and to strengthen the entire dairy sector, the principles of sustainable development is to be taken in account. For upgrading dairying to a larger scale, firstly the farmer's dairy capacity and needs should be improved. Farmers need to improve the quality standards of milk, which would require a strategy to motivate them that dairy is a profitable business other than an optional business. (KUBK-ISFP, 2015).

The combination of proper provision of animal breed, nutrition, health care, processing and marketing is key for bringing success in dairy sectors. Awareness program should be initiated to provide knowledge about animal science and sanitation (Santra, 2018). Moreover, the government should direct, coordinate and regulate the activities of institutions and organizations involved in dairy sector to create and provide favorable environment for small scale dairy farmers (Pant,2017).

There is an utmost need for the disease control mechanisms to be developed as epidemics of FMD, black quarter, HS and other adversely animal health, which eventually reduces milk production and effects the entire dairy sector. Special and aseptic transportation utensils should be assessed by the producers for the safer handling and delivery for the products thereby minimizing the risks of food contamination and spoilage. In this way, consumers can get milk from their choice. Incentives for better quality milk could be suggested around the collection centres on competitive basis.
Further, transparent pricing system for respective cattle and buffalo milk could be encouraged and adequate pricing should be offered based on the fat and SNF content. This might eventually reduce the mal adulteration practices.

Application of block chain technology should be introduced and promoted for ensuring efficient traceability and food security (Shingh et. al, 2020). Adequate trainings should be offered to the farmers regarding the advanced technologies and systematic cattle rearing for generating efficient and active man powers in the dairy sector. The income and price elasticity of consumers should also be considered in the long run for a better pricing system (KUBK-ISFP, 2015)

The total mixed ration can be used to feed the animals in order to get higher milk production. This is in line with the findings of (Schingoethe, 2017). The proper provision of animal breeds, nutrition, health care, processing, marketing along with awareness program is key for bringing success in dairy sectors. This suggestion is in line with (Santra, 2018).

\section{CONCLUSION}

The present study results revealed that the daily milk production in Nepal had been found in small scale and suffering from many obstacles. The per capita availability of milk in Nepal (158.9 grams per day) is far below than the value recommended by WHO (250 grams per day). The intermittent supply of milk via the formal channels causes the dairy cooperatives to function 
inefficiently which adversely affect the country's GDP. Dairy sector contributed nearly 33 percent of the AGDP and 9 percent of total GDP. The dairy sector of Nepal is emerging, and its share to the global milk production is very low ( 0.247 percent of the global milk share). By implementing the solutions and remedies discussed in the paper and via active people's participation, Nepal can be a major player of the dairy sectors in the days to come.

\section{REFERENCES}

[1] CBS, (2012). National population and housing census, Government of Nepal, National planning commission secretariat, national report, Volume 1

[2] COMP-NDDB, (2017). Study on cost of Milk production, Final report, NEPC Research Pvt. Ltd.

[3] Deshmukh, M.S, (2014), Growth and performance of dairy sector in India, Voice of Research,3(2),39-44.

[4] De Vries, A. and Kaylegian, K. (2018). Rapid assessment of the gaps in dairy cattle feeding, management and milk processing that constrain milk quality and quantity in Nepal. Gainesville, FL, USA: Feed the Future Innovation Lab for Livestock Systems

[5] FAO (2010). Food and Agriculture Organization of the United Nations. Dairy Sector Study of Nepal. http://nepalagritech.com.np/

[6] FAOSTAT (2019). Milk production across Countries. Retrieved from https://www.nddb.coop/information/stats/across

[7] GOEC Nepal (2012). Milk marketing strategies study, Final report, National dairy development Board, Harihar bhawan, Lalitpur, Nepal. Retrived from : http://nddb.gov.np/download/publications/Milk\%20Marke ting\%20Strategy\%20Study-Report,2012.pdf

[8] KUBK-ISF, (2015). Study and analysis of Dairy value chain in Nepal, Retrieved from http://kubk.gov.np/authore_gov/images/Dairy\%20Value\% 20Chain\%20Report.pdf

[9] Landes, M., Cessna, J, Kuberka, L. and Jones, k. (2017). India's dairy sector: structure, performance and prospectus, a Report from economic research service, USDA

[10] Livestock statistics of Nepal, (2016). Ministry of livestock development, Planning, monitoring and evaluation division.

[11] Livestock statistics of Nepal (2017). Ministry of livestock development, Panning, monitoring, and evaluation division.

[12] MOAD (2013). Statistical Information on Nepalese Agriculture. Ministry of Agricultural Development. Agribusiness Promotion and Statistics Division. Agri-Statistics Section. Singha durbar, Kathmandu, Nepal.

[13] MoAD (2014/15). Statistical information on Nepalese
Agriculture, Ministry of Agricultural Development, Agribusiness Promotion and Statistics Division, Agri Statistics Section, Singha durbar, Kathmandu Nepal.

[14] MOAD (2016). Statistical Information on Nepalese Agriculture. Ministry of Agriculture Development, Singh Durbar, Kathmandu, Nepal.

[15] MOALD (2019). Statistical Information on Nepalese Agriculture. Ministry of Agriculture Development, Singh Durbar, Kathmandu, Nepal.

[16] Ministry of Finance (2015). Economic Survey, Fiscal Year 2014/2015. Government of Nepal.

[17] NARC (2016). National Agricultural Research Council. Animal Breeding Division. Retrieved from: http://narc.gov.np/animal-breedingdivision/

[18] Nepal Population (2020). Retrieved July 07, 2020, from https://www.worldometers.info/world-population/nepalpopulation

[19] NEPC (2017). Study on efficiency of dairy industries in Nepal, final report, Nepal environment protection center. RFP no.: NDDB/C/RFP/2074/75/02

[20] Neupane N, Neupane H and Dhital, B (2018). A socioeconomic view of status and prospects of goat farming in rural areas of Nepal. J. Inst. Agric. Anim. Sci 35:1-8

[21] NRB. (2018). Nepal Rastriya Bank Monetary Policy 2018/19. Kathmandu: Nepal Rastriya Bank.

[22] Osti, N.P, (2020). Animal Feed Resources and their Management in Nepal. Acta Scientific Agriculture 4.1 :0214.

[23] Osti N.P., Mandal P, Bholas and Shrestha (2013). Milk Yield Response of Bypass Protein feeding (soybean meals) in Dairy animals. Buffalo bulletin, 32(2):834-839

[24] Pande, R.S (1997). Fodder and pasture development in Nepal. Udaya Research and Development Services (P) Ltd. Kathmandu, Nepal, pp 5.

[25] Paneru U, Sharma M, Kolachhapati MR and Shrestha VS (2015) Evaluation of Productive Performance of Cattle in Dairy Pocket Areas of Chitwan and Nawalparasi Districts, J. Inst. Agri C. Anim. Sci, 33: 207-212

[26] Pant, K R. (2017). Cattle farming in Nepal: Why farmers cry. Retrieved from https://www.dairyglobal.net/Markettrends/Articles/20 17/9/Cattle-farming-in-Nepal-Why-farmers-cry183891E/

[27] RAN (2015). Benchmark survey on quality of raw and processed milk in Nepal,,final report, RFP no.: NDDB/C/RFP/2072-73/01, Right to Access Nepal

[28] Santra, S. (2018). Challenges Faced by The Indian Dairy Sector. Retrieved from: https://www.franchiseindia.com/wellness/challengesfaced-by-the-indian-dairy-sector.11159

[29] Sharma, B. and Banskota, K. (2002). Smallholder Dairy Farming in Nepal: Characteristics, Constraints, and 
Development Opportunities, Chapter 5, In: Smallholder Dairy in Mixed Farming Systems of the Hindu KushHimalayas. Issues and Prospects for Development, HKH, Publisher,73-92

[30] Shrestha, H.R., (2000). Small Holder Dairy Farming Systems at Milk Shed Area of Kathmandu Milk Supply Scheme, a study undertaken for Centre for Resource and Environment Studies (CREST) and presented to ICIMOD, Kathmandu, Nepal.

[31] Schingoethe, D. J. (2017). A 100-Year Review: Total mixed ration feeding of dairy cows. Journal of dairy science, 100(12), 10143-10150.

[32] Shingh, S., Kamalvanshi, V., Ghimire, S., \& Basyal, S. (2020). Dairy Supply Chain System Based on Blockchain Technology. Asian Journal of Economics, Business and Accounting, 14(2): 13-19, DOI: https://doi.org/10.9734/ajeba/2020/v14i230189

[33] Thompkinson, D.K. and Sabikhi, L., (2012). Quality Milk Production and Processing Technology, New India publishing agency, pp.4.

[34] Timsina, K. and Regmi, P.P., (2009). Production and marketing dynamics of milk: A case of Chitwan district, Nepal. Journal of Institute of Agriculture and Animal Science, 30, 33-43.

[35] Tiwari, P., and Shingh, S., (2020). Gender Inequality in Nepalese Agriculture: Issues Concerning Sustainability and Food Security, International Journal of Environment, Agriculture and Biotechnology, 5(2):451-458, DOI: https://dx.doi.org/10.22161/ijeab.52.19

[36] Upadhyay, N.D., Timsina, K. P., Gairhe, S., Sapkota, S., Acharya, Y. and Khadka, S., (2017). Growth of livestock sector in Nepal: A perspective on agriculture perspective plan, proceedings of the $10^{\text {th }}$ National workshop on livestock and fisheries research in Nepal, retrived from:file:///C:/Users/Hp/Downloads/Growthoflivestocksec torinNepal.pdf

[37] Upadhyaya, R.M., Joshi, D.D \& Thapa, T.B., (2001). History of dairy development in Nepal. National Dairy Development Board, Nepal.

[38] Upadhyaya, R.M., Singh, S.B., \& Koirala, G.P., (2000). A Policy Review on Milk Holidays. Research Report Series No. 44. Kathmandu: Winrock International. 